\title{
From Mustahik to Muzakki: A Study on the Utilization of Zakat Funds for the Creation and Development of Productives Small Businesses in Lazismu Solo
}

DOI: https://doi.org/10.18196/afkaruna.v17i1.11702

\section{ZULKARNAIN}

IAIN Langsa

Email : Zulkarnaingure@gmail.com

\section{FARKHANI}

Faculty of Shari'ah, IAIN Salatiga

E-mail: farkhani@iainsalatiga.ac.id/farkhani_76@yahoo.com

\section{ABSTRACT}

The purpose of this research is to see the utilization of zakat funds collected and managed by Lazismu Solo, whether it succeeds in converting mustahik into muzaki or obtaining better than expected results. This field research employs qualitative analysis methods, with data collection techniques through in-depth interviews and field observations. This result shows that the ZIS (Zakat, Infaq, and Alms) fund utilization program to convert mustahik into muzakki seen from the side of program implementation's effectiveness and efficiency could be considered successful even though it has not been ideal yet in converting mustahik into muzaki. This success has only led to the mustahik becoming an independent Muslim and regardless of their initial status as a mustahik. In the future, this program must continue to be improved until it actually transforms mustahik into muzakki to become one of the ways to eradicate poverty.

Keyword: Program; Mustahik, Muzakki, Empowering, Zakat

\footnotetext{
ABSTRAK

Tujuan penelitian ini dilakukan adalah untuk melihat pendayagunaan dana zakat yang dikumpulkan dan dikelola oleh Lazismu Solo apakah berhasil merubah
} 
mustahik menjadi muzaki atau memperoleh hasil diluar ekspektasi. Penelitian lapangan ini menggunakan metode analisis kualitatif dengan teknik pengambilan data melalui wawancara mendalam dan observasi lapangan. Hasil dari penelitian ini adalah bahwa program pendayagunaan dana ZIS guna merubah mustahik menjadi muzakki, dilihat dari sisi efektifitas dan efesiensi pelaksanaan program dapat dinilai berhasil walaupun belum ideal, merubah mustahik menjadi muzaki. Keberhasilannya baru sampai menjadikan mustahik menjadi muslim yang mandiri dan berdikari, dan terlepas dari status awalnya, mustahik. Kedepan program ini harus terus ditingkat sampai betul-betul merubah mustahik menjadi muzakki sehingga salah satu mesin penghapus kemiskinan.

Keyword: Program; Mustahik, Muzakki, Pemberdayaan, Zakat

\section{INTRODUCTION}

Globalization, accompanied by advances in information technology, provides information on the countries' progress and failures worldwide concerning their people's welfare. One piece of information uncovers the gap among Muslim countries (among rich and emerging countries). Whereas Islam, which has an economic spiritual-transcendental system, hates inequality. Because of that hatred, Islamic systems and norms provide various solutions so that this gap can be shortened, even eliminated. This solution in terms of modernism is called philanthropy, which is the activity of giving or the habit of giving charity from someone who sincerely sets aside part of his property or resources to be donated to others in need.

As a form of Islamic philanthropy, zakat is a non-negotiable obligation for adherents who have met the criteria as muzakki (zakat payers) because zakat is one element of the five foundations of Islamic pillars Because of the urgency of paying zakat, Caliph Abu Bakr al-Siddiq boldly dared to fight against a group of Muslims who bravely stopped paying zakat after the death of the Rasulullah SAW. Even Abu Bakr swore in the name of Allah that he would really fight against those who disobeyed zakat even though it was only a young goat that they gave at the time of Rasulullah SAW. ${ }^{1}$ On the other hand, one of the Millennium Development Goals (MDGs) agendas to be achieved is to eradicate poverty and hunger. Since it was declared in 2000, the achievements (MDGs) have not been as smooth as desired. Some countries have experienced setbacks. Indonesia is one of several countries experiencing decline, along with the Philippines, Nepal, Timor Leste, Papua New Guinea, Bangladesh, and sub-African countries, which are predominantly Muslim.

Indonesia, which is believed to be the country with the largest Muslim 
community globally, with an extraordinary wealth of natural resources, is ironically still a country that contributes to a sizeable poverty rate. A report from the Central Bureau of Statistics in 2018 revealed that with a population of more than 260 million, the poor in Indonesia reached 25.95 million $(9.82 \%) .{ }^{2}$ It is with the assumption that the poverty standard is based on the intake of carbohydrate needs per head, which is equivalent to 400 thousand rupiahs ( $1 \$ /$ day/person). This figure will clearly more than double if using the United Nations (UN) standard, which is $2 \$ /$ day/ person. ${ }^{3}$

In the latest report, Indonesia's poverty rate was 25.95 million people. It is not a small number - negating the percentage. It indicates that poverty is still the most severe threat to Indonesia, especially Indonesian Muslims. This poverty is the main gate for other religious activists to do apostasy of Indonesian Muslims. To alleviate this poverty, how to raise philanthropic funds (especially zakat) for poverty alleviation programs is needed. Research reports conducted by CSRC UIN Syarif Hidayatullah showed that the potential for zakat of Indonesian Muslims reached 19.3 trillion rupiahs per year. ${ }^{4}$ It is an asset that can alleviate poverty and even improve people's welfare if appropriately managed and directed.

The facts disclose that dozens of Amil Zakat Institutions (LAZ) are on a national scale, the Amil Zakat Agency (BAZ) from the district/city to the central level Zakat Service Units in government and private agencies, Islamic boarding schools, and mosques. However, with the poverty rate that is still high, it is an indicator that the role of zakat fund utilization is still not optimal. It could be that the utilization of zakat funds is just for feeding the poor (mustahik), charity, and less intense to turn the poor person (mustahik) into a person who gives zakat (muzakki) or at least make people no longer willing to receive zakat even though they are not yet capable become muzakki. ${ }^{5}$

In this case, efforts to alleviate poverty continue to be carried out by zakat management institutions in the country. The result is that there are benefits and changes in muzakki's income, but no one has yet dared to show evidence of changing the status of mustahik to muzakki. Like Sela Nur Fitria's (2017) research with the title "Analysis of the Use of Productive Zakat Funds in Increasing Mustahik Income (Study on Dompet Peduli Ummat Darut Tauhid Lampung), the research results only stated that there was an increase in mustahik's income after receiving business assistance. ${ }^{6} \mathrm{~A}$ research done by Nur Fitry Latief dan Fitria Ayu Lestari Niu (2020) entitled Utilization of Productive Zakat in Improving Mustahik Economic Empowerment (Study at 
BAZNAS of Manado City) found that an effort done BAZNAS of Manado City in relieving mustahik from porverty and changing them to be muzakki in the form of Manado Sejahtera program was not running maximally because of the lack of program companion resource. ${ }^{7}$

Furthermore, many Amil Zakat Institutions (LAZ), which have national networks in the sense of having a regional work system with managerial models, monitoring, and work programs, should work properly and seriously to make changes to a mustahik's condition to become mustahik. It can be by channeling funds to one or several community empowerment programs, monitoring, recording program failures or successes, and ending with an evaluation system to make program innovations more successful.

More specifically, Lazismu Solo is a local amil zakat institution in Surakarta City, managed by the Muhammadiyah Surakarta Regional Leadership. It manages zakat, infaq, alms, grants, and waqf funds, which of course, have various innovative programs for managing zakat funds for empowering people. From the various innovations in the zakat fund management, the researcher wants to know about how Lazismu Solo attempts to change the conditions of mustahik into muzaki, especially in the program of productive small businesses' creation and development; whether it succeeded in changing the conditions of mustahik to muzaki, or the results were beyond expectations.

\section{REASEARCH METHOD}

This field research employed data collection techniques through in-depth interviews and field observations. The interviews were done to 2 Lazismu administrators handling the program, and the observation was done by looking directly at the mustahiks' business entities. The data analysis technique used was qualitative analysis. This research's objects were the productive programs of Lazismu Surakarta City, which were directly related to the efforts to utilize ZIS funds (Zakat, Infaq, and Alms) to empower Muslims' economy in Surakarta with the result of converting mustahik into muzaki.

\section{DISCUSSION}

Poverty and Its Derivative Problems in Indonesian Muslims

Even though Indonesia has been participating since the beginning of the G20 association, poverty in Indonesia is still a challenge, which has been continuously strived to address since the early days of independence. Indonesia's serious and planned efforts to reduce poverty since 1969 were by 
making a concept known as Five Years Development (PELITA) named poor family welfare service program. ${ }^{8}$ The concept and implementation initiated by the New Order generally worked well and shifted Indonesia from a poor country to a developing country and had almost become an "Asian Tiger" in the days leading up to the collapse of the New Order regime.

After the reform period, the poverty reduction program remains a priority program for all regimes because it is the mandate of the 1945 Constitution, which must be realized as the Indonesian state's goal.

"Subsequent thereto, to form a government of the state of Indonesia which shall protect all the people of Indonesia and their entire native land, and in order to improve the public welfare, to advance the intellectual life of the people and to contribute to the establishment of a world order based on freedom, abiding peace and social justice, the national independence of Indonesia shall be formulated into a constitution of the sovereign Republic of Indonesia which is based on the belief in the One and Only God, just and humanity, the unity of Indonesia, democracy guided by the inner wisdom of deliberations amongst representatives and the realization of social justice for all of the people of Indonesia."

From the planning of a sustainable poverty reduction program, referring to data from the World Bank, the reduction in the number of poor people in Indonesia was considered successful because it could reduce the average poverty rate per year by $0.8 \%$ compared to several other Asian countries, such as Cambodia, Thailand, China, and Brazil, which were only in the range of $0.1 \%$ per year. This success continued until the end of $2009 .{ }^{10} \operatorname{In} 2020$, the Central Bureau of Statistics (BPS) issued a national census result, which showed that the poverty rate in Indonesia was $9,78 \%$ or 26.42 million people. This figure is still relatively high, especially when it is related to the underdeveloped national economy; the potential for increasing the number of poverties is immense. ${ }^{11}$

At the end of 2018, at the G20 session, Vice President Jusuf Kalla provided a progress report that Indonesia's poverty rate decreased quite significantly, namely one digit of Indonesia's total population of 265 million people, to be precise at $9.82 \%$ or 25.95 million poor people. It was a good achievement even though it received much criticism, especially from senior economists, such as Rizal Ramli.

Judging from the table of poverty figures from year to year and the latest 
BPS release, it exposed that poverty is still a scourge for the Indonesian people's economy and welfare level as can be seen in the table 1 .

Table 1. Poverty in Indonesia

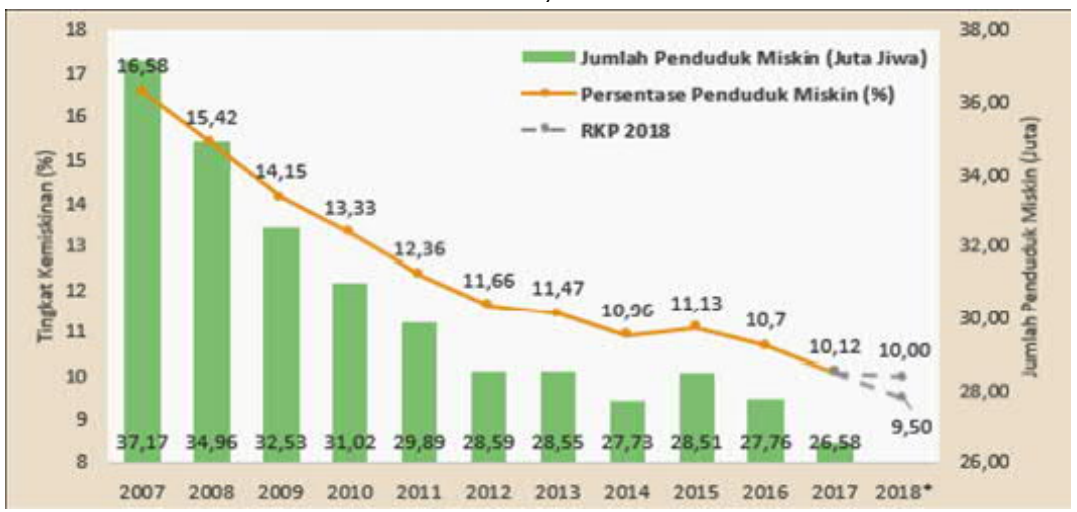

Source: BPS, 2011-2017 September figures

According to the Central Bureau of Statistics report at a press conference on January 9, 2017, and read by Bambang Brojonegoro, the driving factor for reducing poverty is a reduction in inequality, indicated by an improved Gini Ratio and a specific strategy for poverty reduction for 2018. In 2017, the poverty rate reached its lowest point for nearly two decades, namely 10.12 percent. The data release from the Central Bureau of Statistics (BPS) as of September 2017 revealed that the percentage of Indonesia's poor population decreased by 0.58 percentage points (year-on-year). More importantly, in absolute terms, the number of poor people from September 2016 to September 2017 decreased by 1.18 million. If looking at the development of poverty reduction in the last ten years, on average, it only decreased by 500 thousand people per year. Compared to 2016 , there was a notable decrease in poverty in 2017, which was more than double or 1.18 million.

At the same time, it was reported that poverty in rural areas was higher than in urban areas. In September 2017, poverty in rural areas was 13.47 percent or 16.31 million in absolute terms, while urban poverty was 7.26 percent or absolutely 10.27 million people. In the 2010-2014 period, the rate of poverty reduction in rural areas was faster than in urban areas. However, in 2014-2016, poverty reduction in rural areas experienced a slowdown, and there was even an increase in the poverty rate in the 2014-2015 period. Repeating the trend in the 2010-2014 period, there was a decrease in poverty 
in the 2016-2017 period in rural areas faster than in urban areas. Three factors drove poverty reduction in 2017. First, inflation was maintained stable within the target range of 4.0 plus 1 percent. In the period March-September, general inflation was kept at the level of 1.45 percent. The government succeeded in maintaining price stability during the Eid holidays, especially in the food component. The second was an increase in real wages of agricultural laborers by 1.05 percent in the last six months. In this case, poverty in rural areas mainly was from agricultural laborers. With the improvement of the real wage of agricultural laborers, it would help improve the farmers' welfare and reduce poverty in rural areas. Third, there was an integration of poverty alleviation programs, including (i) improving the database for targeting and non-cash distribution through one card; (ii) the distribution of PKH (Family Hope Program) integrated with other assistance to encourage the accumulation of assets/savings and access to other services; (iii) targeted food and energy subsidy reform; (iv) optimizing the use of village funds. ${ }^{12}$

Moreover, the World Bank classified the percentage of Indonesia's population living on less than $\$ 1.25$ per day as those living below the poverty line (in other words, poor). Further, according to the World Bank, if calculating the number of Indonesians living on less than $\$ 2$ per day, the figure would increase even more sharply. It indicates that a large proportion of the Indonesian population lives almost below the poverty line. More recent reports in the Indonesian media informed that about a quarter of Indonesia's population (around 65 million people) lived just above the national poverty line. ${ }^{13}$

The real condition of the poverty rate in Indonesia is even more confusing if paying attention to what state officials said. Minister Puan Maharani said when addressing the increase in BPJS Health contributions, "For PBI (Contribution Assistance Recipients), we still bear the people who are borne by the state. There are 96.8 million and others, so there are almost 120 million poor people who are still covered by the state." 14

From a demographic point of view, urban poverty did look small at $7.26 \%$ (BPS data). However, the social impact of the accompaniment has become a complicated problem for the government in managing the city, such as the emergence of beggars and homeless people, slum areas, illegal parking, prostitution, and the problem of crime. This condition was also conveyed by the Management of Dompet Dhuafa in a 2017 Poverty Outlook Seminar in Jakarta that big cities faced the most severe urban poverty problems because of the large number of poor people, the high density of poor people, and the high 
minimum cost of living. This condition indicates that urban development in the core cities has failed to produce inclusive growth (welfare distribution, pen)..$^{15}$

Due to the complexity of the urban poverty problem, poverty alleviation programs must be carried out with various variations and integrated between lines that handle the various problems caused by urban poverty. In fact, the problem of urban poverty is the responsibility of the city government in particular and the state in general. The poverty problem occurs in Indonesia, a country where most populations are Muslim, meaning that most of the poor are Muslims. Because the largest number of poor people are among the Muslim community, the poverty reduction system in the Islamic teaching system must be implemented. The Islamic teaching system will not work if there is no institution systemically established by the state or by the Muslim community independently for poverty alleviation.

\section{Zakat Fund for Poverty Alleviation (Mustahik)}

\section{Zakat and mustahik funds in Indonesia}

Based on research by BAZNAS, IPB University, and the Islamic Development Bank (IDB), the potential for national zakat was IDR 217 trillion. This figure should have a tremendous impact on poverty alleviation efforts in Indonesia. However, the BAZNAS report revealed that of the zakat potential, only IDR 450 billion could be absorbed and managed by the BAZNAS institution for 2007 , increased to IDR 2.73 trillion in 2013 , or only about $1 \% .{ }^{16}$ In the 2017 National Zakat Statistics book, the potential for zakat in Indonesia was still in the range of IDR 217 trillion, but the management of zakat funds from the previous year increased to $2.9 \%$ of the potential IDR 217 trillion, in the real figure of IDR 6.224 trillion. ${ }^{17}$ Fund management of that size was the accumulation of funds collected by Central BAZNAS, Regional BAZNAS, and Amil Zakat Institutions throughout Indonesia.

From the immense potential of zakat, it should linearly find many muzakki (people obliged to zakat), and the assumption of these muzakkis is that they have entered the productive force (have worked). According to the research results from Clarashinta C Canggih, Khusnul Fikriyah, and Ach. Yasin (2017), ${ }^{18}$ the estimates of muzakki (people obliged to zakat) in Indonesia are described in the following table 2 : 
Table 2. Estimated Population Obligatory of Zakat

\begin{tabular}{lll}
\hline Year & Populations obliged to Zakat Maal & Total Indonesian Population \\
\hline 2011 & $95,643,555$ & $244,808,254$ \\
2012 & $96,635,791$ & $248,037,853$ \\
2013 & $96,632,204$ & $251,268,276$ \\
2014 & $99,967,101$ & $254,454,778$ \\
2015 & $100,133,823$ & $257,563,815$ \\
\hline
\end{tabular}

Source: Data processed from Statistics Indonesia 2012-2016 (BPS), Population by Religion (Ministry of Religion, 2013), World Development Indicator (World Bank, 2016).

From the estimation of the number of muzakki in Indonesia, then by looking at the statistical data on per capita income in the same years, the potential for zakat was obtained as it appears in the table 3 :

Table 3. Potential of Zakat Income in Indonesia

\begin{tabular}{ll}
\hline Year & Potential for Zakat Income \\
\hline 2011 & $58,961,143,222,174$ \\
2012 & $64,086,440,764,997$ \\
2013 & $69,794,542,095,826$ \\
2014 & $78,374,957,309,348$ \\
2015 & $82,609,152,671,724$ \\
2016 & $284,404,218,238,000$ \\
2017 & $271,254,975,000,000$ \\
2018 & $315,350,000,000,000$ \\
\hline
\end{tabular}

Source: Statistics Indonesia 2012-2018 (BPS), Baznas Report 2015-2018, Population by Religion (Ministry of Religion, 2013), Clarashinta C Canggih, Khusnul Fikriyah, and Ach. Yasin (2017)

Based on the database processed by Clarashinta C Canggih et al., it appeared that in their research, the potential for zakat funds was smaller than the research conducted by $B A Z, I P B$, and WIB, including the figures in the realization of zakat funds disbursement. Even so, this figure was still quite prominent if used for the people empowerment programs (mustahik).

In terms of the zakat fund utilization program to maximize the zakat's function, it is how the form of zakat distribution includes eight asnaf (groups of zakat recipients). Seeing the traces of the ZIS fund beneficiary program, since the past, the use of ZIS funds can be classified into four forms:

a. Traditional consumptive in nature, namely the process of distributing directly to the mustahik

b. Creative consumptive, namely the process of consuming other forms of the original product, such as being given in the form of scholarships, 
pottery, hoes, and so on

c. Traditional productive, namely the process of giving zakat in the form of objects or goods known to be productive to regional units that manage zakat, such as giving goats, cows, rickshaws, and so on

d. Creative productive, namely the embodiment of giving zakat in the form of revolving capital, whether for social program business processes, home industry, or additional small business capital

\section{The theory of the utilization of zakat funds}

The meaning of "utilization" in language implies the ability to do business with excellent and valuable results. This kind of understanding, according to Hamzah, contains three things that must exist: capability, process, and results. If paying attention to the three meanings, what is related to utilization is making an effort efficiently and effectively; the efficiency is contained in the process, and the effectiveness is comprised in the results. ${ }^{19}$ In management science, efficiency and effectiveness are always linked in organizing work. However, according to Wiltshire, the relationship between the concepts of effectiveness and efficiency is always unclear. ${ }^{20}$ In simple terms, efficiency is doing things right, while effective is doing the right thing. More specifically, efficiency refers to the costs used in each activity unit which is not so much, whereas effective is the work, activity, or effort performed to achieve a predetermined or desired goal.

In the realm of management, several experts expressed a more detailed understanding of efficiency and effectiveness:

a. Efficiency

Permono Iswardono S explained that what is meant by efficiency is the ratio between output and input, or the amount produced from the input used. ${ }^{21}$ According to him, activity or work can be said to be efficient if it uses a smaller number of units compared to several units used in the same job by another workgroup by producing the same output or using the same input but producing a better or greater output. According to Mouzas, efficiency is not a measure of operational success or productivity, and it is only concerned with the costs used and increasing operating margins. In other words, efficiency is saving in units used (time and cost), which results in the same output as what other people do, even greater or more. ${ }^{22}$

According to Kathryn M. Bartol and Davic C. Martin, efficiency is the 
ability to use available resources to achieve goals. ${ }^{23}$ From the many meanings of efficiency, it can be understood that efficiency is the use of fewer resources (time, cost, energy, or others) by getting planned results, even exceeding expectations.

b. Effectiveness

The words efficiency and effectiveness often go together but have different intentions. In the Great Dictionary of the Indonesian Language, effective means 1) there is an effect (influence and impression); 2) effective or efficacious; 3 ) brings results, is successful (effort, action), and comes into effect. ${ }^{24}$ According to Kumar and Gulati, effectiveness is the extent to which the organization's policies have been achieved. ${ }^{25}$ From this understanding, it can be understood that effectiveness is the ability to achieve results (goals) following the plan.

In connection with the utilization of zakat funds, several researchers provide understanding, including the meaning conveyed by Utami and Lubis. ${ }^{26}$ According to them, the zakat fund utilization is an effort to produce a greater and better benefit by utilizing all existing resources and potential. From consumptive programs that can only be used in the short term, zakat, on the contrary, which is productive, is given in the form of empowerment programs that can be developed in the long term. Thus, the utilization of zakat funds in a broad sense is an effort to make partners more independent, where the partners in question are mustahiks who do not continue to depend on amil. According to Asnaini, the utilization of zakat is distributing zakat funds to mustahik in a productive way. Zakat is given as business capital to develop a business to meet the living necessities throughout life. ${ }^{27}$

According to the researcher, the description of the utilization of zakat funds cannot be separated from the three factors that Hamzah has raised in advance: ability, process, and results. First is the ability, in terms of the zakat fund managers' ability to bring maximum benefits to mustahik. Second, the process is that the zakat fund manager must use zakat resources to the maximum extent possible. The third is the result, meaning that the zakat fund manager must be oriented to provide maximum benefit for the mustahik's interests. ${ }^{28}$ Furthermore, by paying attention to the explanation about the utilization of zakat above, in seeing whether the efforts made by zakat managers are efficient or vice versa, it is by looking at the indicators. One of the opinions related to zakat utilization indicators that can be used as a reference 
is the zakat fund utilization indicator conveyed by Hamzah: 1) efficiency, 2) effectiveness, 3) right amount, 4) on time, and 5) change in the fate of mustahik. As for according to Law No. 23 of 2011 concerning zakat management, the utilization of zakat is stated in Article 27, which includes: zakat can be used for productive efforts in the context of handling the poor and improving the people' quality. b. The utilization of zakat for productive endeavors as meant in paragraph (1) shall be carried out when the mustahik's basic needs have been met.

These indicators require two things: the zakat managers' seriousness (BAZ and LAZ) in utilizing zakat funds through innovative, progressive programs and their ability to change the zakat fund recipients' (mustahik) condition to become no longer zakat recipients or even new muzaki.

Concerning the role of zakat in converting mustahik into muzaki, the Indonesian Ministry of Religion emphasized in its decision No. 373 of 2003 concerning the implementation of Law No. 38 of 1999 concerning zakat management. Article 29 stipulates the procedures for utilizing the results of collecting zakat for productive businesses as follows: (1) conducting a feasibility study, (2) determining the type of productive business, (3) providing guidance and counseling, (4) monitoring, controlling, and supervising, (5) conducting evaluations, and (6) making reports.

Meanwhile, according to the Regulation of the Minister of Religion of the Republic of Indonesia No. 52 of 2014 concerning the terms and procedures for calculating zakat mal and zakat fitrah and the utilization of zakat for productive endeavors, articles 32 to 35 contain instructions for the utilization of zakat for productive efforts in the context of improving the ummah's quality. They must meet the following requirements: a. if the mustahik's basic needs have been met, b. meeting the provisions of the syari'ah, $c$. generating economic added value for mustahik, and d. mustahik living in the zakat management institution's working area. Recipients can be individuals or groups who meet the mustahik criteria and receive assistance from amil zakat in the mustahik's domicile area. Next is the reporting. The most urgent things in the management and distribution that need to be rethought are the zakat fund management's effectiveness, professionalism, and accountability.

\section{Lazismu Solo and the Zakat Fund Utilization Program}

A previous study carried out by Baidhowi regarding the potential of zakat and its utilization for the people's welfare showed unsatisfactory results. ${ }^{29}$ 
Meanwhile, research conducted by Sela Nur Fitria in Lampung revealed encouraging results, namely a significant increase in mustahik's income. ${ }^{30}$ Looking at the previous research results, the writer wants to know whether the utilization of zakat funds by Lazismu Solo is in the pendulum of failure or success.

Lazismu Solo is one of the Amil Zakat Institutions (LAZ), which is quite existing in Surakarta City, which often carries out ZISWAF (Zakat, Infaq, Alms, and Waqf) fundraising activities and distributes them to the community with various fundraising and distribution products. There are two reasons for the establishment of Lazismu. First, the fact that Indonesia is covered with widespread poverty, ignorance, and a shallow index of human development. All of them have consequences and, at the same time, are caused by a weak social justice order. Second, Islamic philanthropy is believed to contribute to promoting social justice and human development, and alleviating poverty. ${ }^{31}$ As a philanthropic institution engaged explicitly in the management and utilization of zakat, infaq, and alms funds under the control of the Muhammadiyah Surakarta Regional Leadership, Lazismu Solo designs and implements zakat fund utilization programs, which are globally categorized into four main programs: education, economy, social-da'wah, and humanity-health. ${ }^{32}$

The target education program is human resource development. The focus is on assisting recipients of ZIS funds for school-age child ren from primary to tertiary education. One form of the program is the provision of scholarships under the program name "Beasiswa Mentari dan Beasiswa Sang Surya [Mentari Scholarship and Sang Surya Scholarship]." The economic empowerment program is called the "Entrepreneurship Program." This program aims to further empower the mustahik's economy through the small businesses' creation and development. The final result expected is that the mustahik who get this program can be independent by increasing their economic standard of living. ${ }^{33}$ The social-da'wah program is the most diverse and often casuistic and follows events in the socio-religious life of Indonesian society at large, for example, house renovations, tahfidz scholarships, natural disaster, and drought relief, and Muslim holiday activities. Meanwhile, the humanity-health programs are more directed at the underprivileged society regardless of their religious origins. 


\section{ZIS Fund Utilization Program Focus for Projections to Convert Mustahik Into Muzakki}

As an amil zakat institution committed to organizational governance, including muzakki financial management with modern management and certainly understands the philosophy of philanthropy and philanthropic goals in Islam, Lazismu takes strategic steps in managing the people's funds, especially in terms of utilizing ZIS funds.

1. ZIS fund utilization strategic policy

Lazismu (Solo) has established a mission to utilize ZIS funds to create a quality socio-economic life for the people as a bulwark for the problems of poverty, underdevelopment, and ignorance in society through various programs developed by Muhammadiyah.

The strategic policies for utilizing ZIS funds by Lazismu nationally are as follows:

a. The priority of the beneficiaries is the needy, poor, and the fisabilillah group.

b. The distribution of ZIS is carried out programmatically (planned and measured) according to the core of the Muhammadiyah movement, namely education, economy, and social-da'wah.

c. Synergizing with assemblies, institutions, autonomous organizations, and Muhammadiyah business charities in realizing the program

d. Synergizing with institutions and communities outside Muhammadiyah to expand the da'wah domain and increase public awareness of the organization

e. Minimizing charity assistance, except for an emergency such as in Eastern Indonesia, areas exposed to disasters, and rescue efforts

f. Intermediation for any business that creates conditions and supporting factors for the realization of an Islamic society that is genuinely in line with the Muhammadiyah 2025 vision

g. Mobilizing the institutionalization of the ZIS movement throughout Muhammadiyah structures and charities. ${ }^{34}$

In order to fulfill that responsibility, Lazismu created a ZIS fund utilization program to change the conditions of mustahik into muzakki. The program is called the "Entrepreneurship Program."

Acknowledged by Reynal, Lazismu has not focused on giving great attention; even so, the empowerment program for economic programs still ex- 
ists. ${ }^{35}$ As evidence, in 2014 and 2015, Lazismu allocated a large number of ZIS funds for entrepreneurship programs, and until now, equivalent programs on a smaller scale are still running.

This program is offered to the community (mustahik). Then, Lazismu Solo carries out data verification and observation stages, entrepreneurial training, providing additional non-usury business capital loans (paying only principal debt), and monitoring business. ${ }^{36}$ This program has been running relatively smoothly with a concise and simple activity report.

Meanwhile, the zakat utilization program in the economic sector under the name "Entrepreneurship Program" was carried out by Lazismu Solo in collaboration with the Community Empowerment Council and Regional Leaders Aisyiyah Surakarta 2015 with a focus on mothers' mustahik. There was no progress report in the form of an accountability report like similar programs in 2014. Until now, the entrepreneurship program to convert mustahik into muzakki is still running. The newest program is the preman insyaf entrepreneurship program. This program is still running but still on a small scale because it has many obstacles. ${ }^{37}$

\section{Analysis of the ZIS Fund Utilization in the Lazismu Solo Entrepreneurship Program to Convert Mustahik into Muzaki}

The Lazismu Solo Entrepreneurship Program is one of the excellent programs for poverty alleviation because this programs' primary objective is to empower the economies of the needy and poor to become economically independent, releasing mustahik from the shackles of poverty.

Judging from the implementation of the ZIS fund utilization program, procedurally, it is under the existing regulations and can be said to be successful. It means that this program's minimum goal is achieved, namely, being economically independent. This success can be seen from at least two things:

1. In the entrepreneurship program to create small and medium enterprises, there were two program recipients (Mrs. M, a chicken porridge trader, and the preman insyaf community, a traditional "hik" shop business). From having no working capital, various coaching procedures were carried out according to the organization's internal policies (work programs) and existing regulations. Until the monitoring and evaluation, everything went well and was successful. 
The success of this program to date can be seen from the fact that their business entities are still running smoothly, and they are not a burden to the surrounding community and independent even though they have not succeeded in becoming a muzakki.

From the aspect of the utilization of meaning content, it includes capabilities, processes, and results. ${ }^{38}$ In terms of capabilities, Lazismu Solo has already had the ability, namely the aspect of fundraising and modern managerial capabilities. From the process side, it was generally done well. Meanwhile, for the results, it was quite successful even though it was not optimal.

From the aspect of efficiency, referring to the costs used in each activity unit that was not so much, it could be considered efficient because the funds spent for this entrepreneurship program were not that big. Meanwhile, in terms of effectiveness related to work, activities, or efforts to achieve predetermined or desired goals, it could be said to be effective because mustahik recipients of this program could be economically independent even though they have not yet reached the stage of changing from mustahik to muzakki, and it was only in just one year.

2. In the form of small and medium business development initiated from Bank Bukopin Syari'ah's CSR (Corporate Social Responsibility) funds, entrepreneurship programs could be declared to be running well and succeeding. CSR fund was used by Lazismu to fund the business development program.

From the fund of Bukopin CSR, Lazismu Solo makes an empowerement program for mustahik in the form of capital loan without interest to create and develop small enterprise. The fund was distributed to 14 registered mustahiks. But, Lazismu just registered the name of mustahiks, the kinds of business, adrees and the way to pay the loan off. The accompaniment for the business developmet and financial management were not given well and the control system was weak. This constrain was due to the lack of human resource and expert in empowering small business. Therefore, the first goal to turn mustahik into muzakki was not reached.

Of the 14 mustahik merchants and small service businesses that were given capital in the form of loans without usury by Lazismu Solo, 11 were considered successful, and three failed. In terms of percentage, $78.5 \%$ of these entrepreneurship programs were successful. Eleven mustahiks who received business capital from Lazismu stated that the program was very 
good and beneficial for their business continuity. However, it was not possible for business development because the loan funds were not in large amounts, and it is hoped that the program will still exist.

Table 4. Mustahik as the capital receiver

\begin{tabular}{|c|c|c|c|c|}
\hline No & Name & $\begin{array}{l}\text { Kinds of } \\
\text { business }\end{array}$ & Capital Loan & Information \\
\hline 1 & $\begin{array}{l}\text { RM } \\
\text { Hanendyo } \\
\text { Saputro }\end{array}$ & $\begin{array}{l}\text { Bubur } \\
\text { Ayam }\end{array}$ & Rp. 2.000.000, & $\begin{array}{l}\text { The loan is not paid off, } \\
\text { Mustahik disappeared }\end{array}$ \\
\hline 2 & $\begin{array}{l}\text { Listyo } \\
\text { Wulandari }\end{array}$ & $\begin{array}{l}\text { Vegetable } \\
\text { seller }\end{array}$ & Rp. 1.800.000,- & $\begin{array}{l}\text { The loan is paid off, the } \\
\text { business is still running }\end{array}$ \\
\hline 3 & Pundriyatmi & Selat & Rp. 1.500.000,- & the business is still running \\
\hline 4 & Indri Hastuti & $\begin{array}{l}\text { Jenang } \\
\text { Sera }\end{array}$ & Rp. 1.000.000,- & the business is still running \\
\hline 5 & $\begin{array}{l}\text { Kholifah } \\
\text { Rizkia S }\end{array}$ & Kedai IPM & Rp. 1.500.000,- & $\begin{array}{l}\text { The business is off, the } \\
\text { loan is given back }\end{array}$ \\
\hline 6 & $\begin{array}{l}\text { Dwi Arti Erma } \\
\text { Susanti }\end{array}$ & $\begin{array}{l}\text { Pondok } \\
\text { Makan } \\
165\end{array}$ & Rp. 1.500.000,- & the business is still running \\
\hline 7 & $\begin{array}{l}\text { Meita Tri } \\
\text { Wahyuningsih }\end{array}$ & Tempe & Rp. 1.200.000,- & $\begin{array}{l}\text { The loan is not paid off, } \\
\text { Mustahik disappeared }\end{array}$ \\
\hline 8 & Sri Mulyo & HIK & Rp. 1.500.000,- & the business is still running \\
\hline 9 & Darmini & HIK & Rp. 1.500.000,- & $\begin{array}{l}\text { The loan is paid off, the } \\
\text { business is still running }\end{array}$ \\
\hline 10 & $\begin{array}{l}\text { Wagino Hadi } \\
\text { Pranoto }\end{array}$ & $\begin{array}{l}\text { Dwi Putra } \\
\text { publisher }\end{array}$ & Rp. 2.000.000,- & the business is still running \\
\hline 11 & $\begin{array}{l}\text { Muhammad } \\
\text { Sunarwo }\end{array}$ & $\begin{array}{l}\text { UD } \\
\text { Sumber } \\
\text { Rejeki }\end{array}$ & Rp. 1.800.000,- & the business is still running \\
\hline 12 & Sri Mulyani & $\begin{array}{l}\text { Zany bag } \\
\text { shop }\end{array}$ & Rp. 1.600.000,- & $\begin{array}{l}\text { The loan is paid off, the } \\
\text { business is still running }\end{array}$ \\
\hline 13 & $\begin{array}{l}\text { Davin } \\
\text { Nugroho }\end{array}$ & Computer & Rp. 1.600.000,- & $\begin{array}{l}\text { The business changes, } \\
\text { The loan is not paid off, } \\
\text { Mustahik disappeared }\end{array}$ \\
\hline 14 & Hartoko & HIK & Rp. 1.200.000,- & the business is still running \\
\hline
\end{tabular}

The above table 4 reveals that existence of the eleven mustahik recipients of ZIS utilization funds from Lazismu could be confirmed. The business continued, but there was no report from Lazismu Solo that they had become muzakki. Meanwhile, the three recipients of loan capital could no longer be confirmed because their place of residence had moved and could not be confirmed either through the telephone number in Lazismu data or by visiting their original address.

When analyzed from the aspect of procedures and regulations regarding 
the utilization of ZIS funds for productive businesses, it was very much under these existing regulations. Meanwhile, the elements of capability, process, and results contained in terms of utilization were sufficient.

From the aspect of efficiency and effectiveness; the efficiency of this entrepreneurship program for developing trade and services could be stated to be efficient in terms of funding or capital lending. It indicates that there was a return capital to Lazismu, and in terms of the time, that was not too long, which was only one year. Meanwhile, from the effectiveness aspect, it could be declared effective because this program's success reached 78.5\%.

Apart from all the positive values obtained by Lazismu in managing ZIS funds, especially for entrepreneurship programs, there are important notes as corrections and inputs, especially in the philosophical aspects of Islamic teachings' philanthropic goals. Based on the Qur'an Surah al-Taubah verse 60, which mentions eight asnaf recipients of alms (zakat), it indicates that the problem must be solved by zakat until there are no more mustahik, as mentioned in verse. This meaning is not an illusion because, in the history of managing ZIS funds in the Islamic world, there has been evidence that there were no more Muslims, especially those who were willing to accept funds from state baitul mal, whose majority of funds were from various kinds of philanthropy in Islam, including zakat.

\section{CONCLUSION}

Lazismu Solo, as one of the ZIS fund managers, strives with various activity programs to overcome urban poverty problems, especially for Muslims in Surakarta City. There are four categories of program areas: education, economy, socio-da'wah, and humanity-health. In the economic sector, the "Entrepreneurship Program" is a program that aims to empower mustahik economically so that they turn into muzakki, or at least become economically independent. The program form is in the form of creation and development of mustahik small and medium enterprises.

Viewed from the effectiveness and efficiency of implementing zakat fund utilization programs for productive economic enterprises, it could be considered effective and efficient even though the results were not ideal for the program's goal, namely, converting mustahik into muzakki. The results obtained so far have only made the mustahik become an economically independent Muslim and regardless of his initial status, but have not turned into a muzaki. This result is constrained by limited human resources and the amount 
of funds for economic empowerment programs. For further research, what needs to be done is assistance in the creation and development of mustahik small and medium enterprises by zakat management institutions. For this purpose, Lazismu thought of collaborating with the Faculty of Economics or the Business Incubation Center at Muhammadiyah University.

\section{ENDNOTES}

1 Yunahar Ilyas, Cakrawala al-Qur'an, (Yogyakarta: Suara Muhammadiyah, 2003): 104.

2 https://www.bps.go.id/pressrelease/2018/07/16/1483/, in 2020 the poor in Indonesia reached 26.42 million see https:/ www.bps.go.id/pressrelease/2020/ 07/15/1744/

3 Amer Roubaie, "Dimensi Global Kemiskinan di Dunia Muslim: Sebuah Penilaian Kuantitatif," Majalah Pemikiran dan Peradaban Islam ISLAMIA, Vol. 11, No. 3. (2005):81.

4 Irfan Abu Bakar dan Chaider S. Bamuali [ed.], Filantropi Islam dan Keadilan Sosial; Studi tentang Potensi, Tradisi dan Pemanfaatan Filantropi di Indonesia, Jakarta: Center for the Study of Religion and Culture (CSRC), 2006): 202.

5 PBB-UIN Syarif Hidayatullah dalam Yusuf Wibisono, "Ekonomi Sedekah", http://www.tazkiaonline.com, diakses tanggal 7 Pebruari 2019.

6 Sela Nur Fitria, "Analisis Pendayagunaan Dana Zakat Produktif dalam Meningkatkan Pendapatan Mustahik (Studi pada Dompet Peduli Ummat Darut Tauhid Lampung)," Skripsi, (IAIN Raden Intan Lampung 2017).

7 Nur Fitry Latief, Fitria Ayu Lestari Niu, "Utilization of Productive Zakat in Improving Mustahik Economic Empowerment (Study at BAZNAS of Manado City)", IJAFAP Journal, Vol. 3 No. 2, (2020):.

8 Ketut Sudibia, Anak Agung Istri Ngurah Marhaeni, "Beberapa Starategi Pengentasan Kemiskinan di Kabupaten Karangasem Provinsi Bali”, Jurnal Piramida, Vol. ix No. 1, (2012).

9 Pembukaan UUD 1945 (Alinea ke-4 UUD 1945).

10 Budiman Rusli, "Analisis Kebijakan Penanggulangan Kemiskinan di Provinsi Jawa Barat," Laporan Penelitian Mandiri Pascasarjanan FISIP Universitas Padjajaran, 2013.

11 https://www.bps.go.id/pressrelease/2020/07/15/1744/.

12 Siaran Pers BPS tanggal 9 Januari 2017.

$13 \mathrm{https} / /$ www.indonesia-investments.com/id/keuangan/angka-ekonomi-makro/ kemiskinan/item301.

14 setkab.go.id, Jumat (6/9/2019).

15 https://www.republika.co.id/berita/dunia-islam/wakaf.

16 Clarashinta Canggih Khusnul Fikriyah, Ach. Yasin, "Potensi dan Realisasi Dana Zakat Indonesia," al-Uqud: Journal of Islamic Economics, 1, (2017): 16.

17 Baznas, Statistik Zakat Nasional 2017, (Jakarta: Baznas, 2018). 
18 Clarashinta Canggih, Khusnul Fikriyah, dan Ach. Yasin, 2017. "Potensi dan Realisasi Dana Zakat Indonesia”, al-Uqud: Journal of Islamic Economics, vol. 1.

19 Hamzah, "Pendayagunaan Zakat pada Badan Amil Zakat Nasional dalam Meningkatkan Kesejahteraan Umat,” Disertasi, (Jakarta: Sekolah Pascasarjana UIN Syarif Hidayatullah, 2009).

20 Wiltshire dalam Sudiyono, "Efesiesi dan Efektifitas dalam Manajemen Pendidikan,” Makala hada Seminar Nasional ISMAPI di Makassar, 19 Juni 2004.

21 Permono Iswardono S dan Darmawan, "Analisis Efesiensi Industri Perbankan di Indonesia (Studi Kasus Bank-Bank Devisa di Indonesia," Jurnal Ekonomi dan Bisnis, Vol. 15, No. 1 (2000).

22 S. Mouzas, "Efeciency versus Effectiveness in Bussines Networks," Journal of Business Reasearch, 59, (2006).

23 Kathryn M. Bartol dan Davic C. Martin, Management, (New York: Mc Graw Hill Inc, 1991).

24 Departemen Pendidikan Nasional, Kamus Besar Bahasa Indonesia, (Jakarta: Balai Pustaka, 2000).

25 Sunil Kumar dan R. Gulati, "Measuring Effeciency, Effectiveness and Performance of Indian Public Sector Banks," International Journal of Productivity and Performance Management, 59 (2010).

26 Siti Halida Utami \& Irsyad Lubis, "Pengaruh Pendayagunaan Zakat Produktif terhadap Pemberdayaan Mustahik di Kota Medan," Jumal Ekonomi dan Keuangan, Vol. 6 No. 2, (2014).

27 Asnaini. Zakat Produktif dalam Prespektif Hukum Islam, (Yogyakarta: Pustaka Pelajar, 2008): 134.

28 Hamzah, 2009. "Pendayagunaan Zakat pada Badan Amil Zakat Nasional dalam Meningkatkan Kesejahteraan Umat”, Disertasi Sekolah Pascasarjana UIN Syarif Hidayatullah Jakarta

29 Baidlowi, "Potensi Bazis untuk Meningkatkan Kesejahteraan Masyarakat di Yogyakarta,” Lapoaran Penelitian 2003.

30 Fitria, Sela Nur. 2017. "Analisis Pendayagunaan Dana Zakat Produktif dalam Meningkatkan Pendapatan Mustahik (Studi pada Dompet Peduli Ummat Darut Tauhid Lampung),"Skripsi, IAIN Raden Intan Lampung

31 Wawancara dengan Reynal, tanggal 10 Oktober 2019.

32 Wawancara dengan Muhammad Isnan tanggal 12 Oktober 2019.

33 Wawancara dengan Reynal 12 Oktober 2019.

34 https://lazismu.org, diunduh 13 Oktober 2019.

35 Wawancara tanggal Reynal 10 Oktober 2019.

36 Wawancara dengan Muhammad Isnan tanggal 12 Oktober 2019.

37 Wawancara dengan Reynal tanggal 10 Oktober 2019.

38 Hamzah, 2009. "Pendayagunaan Zakat pada Badan Amil Zakat Nasional dalam Meningkatkan Kesejahteraan Umat”, Disertasi Sekolah Pascasarjana UIN Syarif Hidayatullah Jakarta 


\section{REFERENCES}

Abu Bakar, Irfan dan Chaider S. Bamuali. 2006. Filantropi Islam dan Keadilan Sosial; Studi

tentang Potensi, Tradisi dan Pemanfaatan Filantropi di Indonesia. Jakarta: Center for the

Study of Religion and Culture (CSRC)

A. Najib, Tuti dan Ridwan al-Makassary. 2006. Wakaf, Tuhan dan Agenda Kemanusiaan;

Studi tentang Wakaf dalam Perspektif Keadilan Sosial di Indonesia. Jakarta: Center for the

Study of Religion and Culture (CSRC)

Asnaini. 2008. Zakat Produktif dalam Prespektif Hukum Islam. Yogyakarta: Pustaka Pelajar

Baidlowi. 2003. "Potensi Bazis untuk Meningkatkan Kesejahteraan Masyarakat di Yogyakarta."

Lapoaran Penelitian

Bartol, Kathryn M. dan Davic C. Martin. 1991. Management. New York: Mc Graw Hill Inc

Baznas. 2018. Statistik Zakat Nasional 2017. Jakarta: Baznas

Canggih, Clarashinta, Khusnul Fikriyah, Ach. Yasin. 2017. "Potensi dan Realisasi Dana Zakat

Indonesia", al-Uqud: Journal of Islamic Economics, vol. 1

Fitria, Sela Nur. 2017. "Analisis Pendayagunaan Dana Zakat Produktif dalam Meningkatkan

Pendapatan Mustahik (Studi pada Dompet Peduli Ummat Darut Tauhid Lampung)," Skripsi, IAIN Raden Intan Lampung

Hamzah. 2009. "Pendayagunaan Zakat pada Badan Amil Zakat Nasional dalam Meningkatkan

Kesejahteraan Umat", Disertasi Sekolah Pascasarjana UIN Syarif Hidayatullah Jakarta

Ilyas, Yunahar. 2003. Cakrawala al-Qur'an. Yogyakarta: Suara Muhammadiyah Iswardono S, Permono dan Darmawan. 2000. "Analisis Efesiensi Industri Perbankan di Indonesia

(Studi Kasus Bank-Bank Devisa di Indonesia)”, Jurnal Ekonomi dan Bisnis vol. 15 no. 1

Kerbo, Horald R. 1996. Social Stratification and Inequality; Class Conflict in Historical and

Comparative Perspective. Boston: WCB/McGraw-Hill

Kumar, Sunil. dan R. Gulati. 2010. "Measuring Effeciency, Effectiveness and Performance of

Indian Public Sector Banks", International Journal of Productivity and Performance Management vol. 59

Latief, Nur Fitry and Fitria Ayu Lestari Niu, "Utilization of Productive Zakat in Improving Mustahik Economic Empowerment (Study at BAZNAS of Manado 
City)", IJAFAP Journal, Vol. 3 No. 2, (2020): 13-25.

Mouzas, S. 2006. "Efeciency versus Effectiveness in Bussines Networks", Journal of Business

Reasearch vol. 59

Nasional, Departemen Pendidikan. 2000. Kamus Besar Bahasa Indonesia. Jakarta: Balai Pustaka

Roubaie, Amer. (2005). "Dimensi Global Kemiskinan di Dunia Muslim: Sebuah Penilaian

Kuantitatif”, Majalah Pemikiran dan Peradaban Islam ISLAMIA vol. 11 no. 3

Rusli, Budiman. 2013. "Analisis Kebijakan Penanggulangan Kemiskinan di Provinsi Jawa Barat”,

Laporan Penelitian Mandiri. Bandung: Pascasarjanan FISIP Universitas Padjajaran

Sudibia, Ketut and Anak Agung Istri Ngurah Marhaeni, "Beberapa Starategi Pengentasan Kemiskinan di Kabupaten Karangasem Provinsi Bali”, Jurnal Piramida, Vol. ix No. 1, (2012): 1-14.

Sudiyono. 2004. "Efesiesi dan Efektifitas dalam Manajemen Pendidikan”, Makalah pada Seminar

Nasional ISMAPI di Makassar

Surakarta, Badan Pusat Statistik. 2019. Kota Surakarta dalam Angka 2019. Surakarta: BPS

Surakarta

Utami, Siti Halida \& Irsyad Lubis. 2014. "Pengaruh Pendayagunaan Zakat Produktif terhadap

Pemberdayaan Mustahik di Kota Medan”, Jurnal Ekonomi dan Keuangan vol. 6 no. 2 Yusuf Wibisono, "Ekonomi Sedekah", http://www.tazkiaonline.com, diakses tanggal 7 Februari

2019.

Ketut Sudibia, Anak Agung Istri Ngurah Marhaeni, "Beberapa Starategi Pengentasan Kemiskinan di Kabupaten Karangasem Provinsi Bali”, Jurnal Piramida, Vol. ix No. 1, (2012): 1-14. 